\title{
A Research into the Influence of Individual Differences on the Effect of Second Language Acquisition - A Case Study
}

\author{
$\mathrm{Zi} \mathrm{Yu}{ }^{1}$, Yuyang $\mathrm{Fu}^{2}$, Wei Guo ${ }^{3}$ \\ ${ }^{1}$ School of Foreign Languages, China Jiliang University \\ ${ }^{2}$ School of Communication, Kong Kong Baptist University \\ ${ }^{3}$ Shinyway Education
}

\begin{abstract}
The paper makes an exploratory research among 400 university students to find out the influence of individual differences on the effect of second language acquisition between high achievers and low achievers from the perspective of motivation, strategies and characters. It also analyzes existing problems. Research results will gain some enlightenment for teaching and learning activities, and facilitate learners achieve a better learning effect.
\end{abstract}

KeyWords. individual differences; second language acquisition; effect

\section{Introduction}

Recent years, the number of English majors is increasing sharply. With the fierce competition, students face enormous pressure. When learning English, some students try very hard but find it difficult to learn it well compared with the excellent learners. Therefore it is crucial to find out the key factors affecting second language learning and help students achieve satisfactory results in learning. This study makes an exploratory research among 400 university students in Xia Sha Higher Educational Zone to explore the influences of individual differences affecting English learning, to find out the factors affecting the effect of second language acquisition (SLA) between high achievers and low achievers from the perspective of motivation, strategies and characters, to gain some enlightenment for teaching and learning activities.

\section{Literature review}

\subsection{The origin and development of individual differences on second language acquisition}

The study on second language acquisition began in the west, from the end of the 1960s to the early 1970s. The classic paper The Significance of Learners' Errors written by S. P. Corder published in 1967 made a milestone in this research area. Altman (1980) found out the factors affecting learners' individual differences, including age, sex, language learning experience of the past, the native language proficiency, character, linguistics, motivation and attitude, intellectual factor, cognitive strategies and methods, etc.. Skehan (1989) also argued that the factors of learners in individual differences include linguistics, language learning strategies, and motivation, cognition 
and emotion, character, intelligence, cognitive styles, anxiety, etc. Altman and Skehan further studied social and psychological factors, cognitive style and brain hemispheric lateralization, learning strategies, memory and gender factors. As a representative of foreign scholars in linguistics, Ellis (1989) established the system of second language acquisition theories and put forward the basis of the theoretical mode. He divided individual differences into two categories: personal factors and common factors. The system classification makes the theory of individual differences in second language acquisition be carried out not only in depth but also in breadth .

\subsection{The Elements of the Research}

\subsubsection{Motivation}

Cardner and Lamber are the pioneers in the field of motivation research in second language acquisition. Before they put forward motivation doctrine, people generally believed that learning a foreign language should have language aptitude, which is the determining factor affecting the effect of learning. They put forward that attitude can affect people's assumptions of second language acquisition effects directly, and they gradually constructed the model of social education based on social psychology and integrative motivation theory in the later study. The establishment of this model promotes the progress of second language acquisition research. However, in the late 1980s, this doctrine has been challenged and criticized. Based on the theory of Cardner's social education mode, Trambley and Cardner (1995) proposed extension motivation theory, in the original foundation with mainstream motivation psychology expectations theory and objective theory. At the same time, Dornyei and Clement (1994) absorb the psychology of the mainstream motivation theory and put forward foreign language learning theory with a three-dimensional model, which embodies the language learning motivation and the organic integration of teaching situation, provides support for the motivation validity research in school education. Dornyei promoted motivation theory to another climax with a more positive education model in 1994 .

\subsubsection{Strategies}

Learning strategies began from the 1960's to early 1970's. Carton $(1966,1971)$ declared that language learning is a process of problem solving. Cardner and Lambert (1971) conducted further study in manner and the motivation field in the early 1970's. After 1980's, scholars put the strategy of second language acquisition in the framework of the cognitive theory and discover the effects of learning strategies in language learning. O'Malley (1987) put forward three points on learning strategies. Since 1990s, with further exploration and discovery, scholars do not just analyze the success of language learning from the perspective of learning strategies. Skehan (1989), O’Malley (1987) and Ellis (1994) made a detailed study on classification of learning strategies based on original theories. The current classification was mainly proposed by Ellis in 1994, who divided the learning strategies into direct and indirect aspects. Based on the development of educational psychology, Rubin $(2001,2005)$ introduced the concept of selfregulation and the individual differences in the study of second language acquisition. Rubin's selfmanagement concept is an extension to the traditional learning strategies, indicating a new direction for the research of second language acquisition.

\subsubsection{Personality}

Studies have shown that personality influence second language acquisition. Freud (1899) declared that social and human nature is opposite. In this case, people are always in repressed, and therefore people's mental energy cannot be released, resulting in a variety of anxiety. Anxiety will hinder learners who are not good at second language learning from learning smoothly. However, it plays 
an opposite role to excellent learners. During the study of the personality factors, Jung (1976) demonstrated that each one is born with certain adaptive approaches for concatenating relationship between outward and inward, namely, different people may show more or less extroverted in relation to others. However, the current individual differences theory is put forward by Eysenck, which obtains the inside and outside tendentious theory and discusses the system theory in anxiety.

\section{Methodology}

\subsection{Research objects}

The participants in this research are the English majors in the universities of Xia Sha Higher Educational Zone, including China Jiliang University, Hangzhou University of Electronic Technology, Zhejiang University of Finance and Economics, Hangzhou Normal University, Zhejiang University of Science and Technology, Modern Science and Technology College of China Jiliang University. Among research subjects, junior and senior students are the majority. During the period of the research, the objects have already formed their individual characteristics with their learning motivation, learning personality and learning strategies, which have high stability.

\subsection{Research Methods}

\subsubsection{Instruments}

Both questionnaire and interview survey are employed in the research. The questionnaire consists of 25 questions designed to measure participants' English achievement from personality, motivation and strategy, based on Gardner and MacIntyee's (1993) motivation test scale, Dornyei's (1994) foreign language learning motivation components, Skehan's (1989) classification, Oxford (1990) learning strategies system. The consequences of the research are put into a computer. Each result will be checked three times to ensure the correctness of the transformation. Missing responses will be screened out.

\subsubsection{Date Collection}

The questionnaire is issued to students in class and collected back at the scene to ensure the number,quality and reliability. For the entire questionnaires (a total of 400 questionnaires), effective part achieves a coefficient of $86.25 \%$. All the coefficients are high enough to be used in the subsequent data analyses. 15 high achievers and 15 low achievers of different universities are recommended by teachers to conduct the interview.

\subsubsection{Date Analysis}

The data collected are analyzed with the help of Excel and the Statistical Package for Social Science (SPSS18.0).The quantitative analysis is divided into the following procedures. Firstly, data is analyzed with the help of Statistical Package, which makes the mixed material be screened out and ensure the materials' system integrity and reliability. Secondly, with the help of SPSS 18.0, the mixed material classification is obtained and corresponding statistical charts are made, and then descriptive statistics is used to identify the learners' motivation, strategies and personality types. Furthermore, strategies that learners used will be found out. Finally canonical correlation analysis is conducted, comparing the characteristics of the 15 high achievers' with the 15 low achievers, learners's study situation can be analyzed eventually. 


\section{Findings and discussion}

\subsection{Motivation}

Eight questions related to motivation are included from the aspects of language, learners and learning contexts. Measurement of the content in the following table presents learners' response in eight major areas: (1) the desire to target; (2) motivation of English learning; (3) oral communication ability; (4) attitude toward target language; (5) the degree of effort to obtain the target; (6) the degree of satisfaction when accomplishing a task; (7) the type of English teacher; (8) methods taken by teachers.

Table 1. Motivation Test of English Majors in Xia Sha Higher Educational Zone

\begin{tabular}{|c|c|c|c|}
\hline Item & Measurements & Mean & Std. Deviation \\
\hline The desire to SLA & $\begin{array}{l}\text { 1. Get involved in learning and bring happiness } \\
(40.17 \%) \\
\text { 2. Gain parents' recognition }(18.79 \%) \\
\text { 3. Get good results in English contest }(12.43 \%) \\
\text { 4. Get high marks in English exams }(11.56 \%) \\
\text { 5. To avoid punishment }(5.2 \%) \\
\text { 6. Other reasons }(11.85 \%)\end{array}$ & 2.5838 & 1.7308 \\
\hline $\begin{array}{l}\text { Need for } \\
\text { achievement }\end{array}$ & $\begin{array}{l}\text { 1. Pass TEM-4 and TEM-8 }(19.08 \%) \\
\text { 2. Have advantages in getting a job }(35.55 \%) \\
\text { 3. Strength in spoken English }(23.41 \%) \\
\text { 4. Interest in foreign culture }(13.87 \%) \\
\text { 5. Make foreign friends }(3.76 \%) \\
\text { 6. Show and improve self-confidence }(11.85 \%)\end{array}$ & 3.341 & 1.554 \\
\hline Confidence & $\begin{array}{l}\text { 1. Very confident and express fluently }(28.04 \%) \\
\text { 2. Not fluent enough but can accurate expression of } \\
\text { the content }(43.06 \%) \\
\text { 3. Nervous and forget how to express }(28.9 \%)\end{array}$ & 2.3266 & 0.7615 \\
\hline $\begin{array}{l}\text { Integrative } \\
\text { orientation }\end{array}$ & $\begin{array}{l}\text { 1. You think foreigners are warm and friendly } \\
(15.03 \%) \\
\text { 2. You think foreigners are of great differences to } \\
\text { us, but can accept }(45.09 \%) \\
\text { 3. You think foreigners are apathy and dislike to } \\
\text { contact with them }(25.15 \%) \\
\text { 4. Cannot accept foreigners' behavior, and disgust } \\
\text { them }(14.74 \%)\end{array}$ & 2.9162 & 0.9673 \\
\hline $\begin{array}{l}\text { The intensity of } \\
\text { motivation }\end{array}$ & $\begin{array}{l}\text { 1. Have tried the best to study }(19.08 \%) \\
\text { 2. Work harder than most students }(36.71 \%) \\
\text { 3. Same with most of the students }(30.64 \%) \\
\text { 4. They don't study hard }(13.59 \%)\end{array}$ & 2.6098 & 1.0102 \\
\hline The attitude of SLA & $\begin{array}{l}\text { 1. Proud to complete the task }(23.99 \%) \\
\text { 2. Feel relaxed when reduce a task }(50.29 \%) \\
\text { 3. No special feeling }(25.72 \%)\end{array}$ & 2.3266 & 0.7615 \\
\hline Assessment of SLA & $\begin{array}{l}\text { 1. Strong affinity and energy type }(21.39 \%) \\
\text { 2. Strong affinity type only }(16.19 \%) \\
\text { 3. Energy type only }(15.03 \%) \\
\text { 4. Authority type }(47.4 \%)\end{array}$ & 2.8295 & 0.7961 \\
\hline Assessment of SLA & $\begin{array}{l}\text { 1. Demonstration of the way }(15.32 \%) \\
\text { 2. Mission statement }(34.69 \%) \\
\text { 3. Feedback effect }(50 \%)\end{array}$ & 2.9075 & 0.799 \\
\hline
\end{tabular}


From the table above, 139 of the 346 learners hold integrative motivation in the language level which accounts for $40.17 \%$, 48 learners hold integrative motivation in learner context, which only covers $13.87 \%$. They show low internal interest in English learning. In the area of target language attitude, about $60.12 \%$ learners hold a positive attitude toward English-speaking country, 39.89\% hold a negative attitude. $19.08 \%$ learners have strong motivation in learning, and $13.59 \%$ learners with low intensity motivation. When asked about the satisfaction of the task completion, 23.99\% students are proud to complete the task, 50.29\% learners feel relaxed for reducing a task. Regarding situational motivation, most participants think teaching style and the role of English teachers are especially valued. In the study, the singleness of teaching method and lack of appetency are quite serious. Further analysis indicate that the 138 learners with integrative motivation have a strong interest in English learning. Expectancy for success is important in classrooms. Learners with strong motivation persist longer on tasks and achieve higher than those whose expectations are lower. Learners who hold integrative motivation are more likely to learn English with a strong interest and consider English as a communicative tool. They want to communicate with foreigners and prefer to learn more about foreign cultures. However, learners with instrumental motivation will learn English with utilitarian purposes. Their enthusiasm is easy to wane with the changing situation, and prone to emerge the phenomenon of "silent English". In fact, most learners hold two kinds of motives; however, what counts is the dominant motivation and the intensity of motivation. In addition, teaching style and the role of English teachers are especially valued. The strong affinity and energy type teachers will help learners' learning and authoritative type teacher will cause obstruction. It indicates that learning situation exerts limited influence on learners' motivation.

Table 2. The Chi-Square Tests

\begin{tabular}{|c|c|c|c|c|c|}
\hline & Value & df & $\begin{array}{l}\text { Asymp. Sig. } \\
\text { (2-sided) }\end{array}$ & $\begin{array}{l}\text { Exact Sig. } \\
\text { (2-sided) }\end{array}$ & $\begin{array}{l}\text { Exact Sig. } \\
\text { (1-sided) }\end{array}$ \\
\hline Pearson Chi-Square & $22.941^{\mathrm{a}}$ & 1 & .000 & & \\
\hline Continuity Correction ${ }^{\mathrm{b}}$ & 19.548 & 1 & .000 & & \\
\hline Likelihood Ratio & 29.274 & 1 & .000 & & \\
\hline Fishe's Exact Test & & & & .000 & .000 \\
\hline Linear-by-Linear Association & 22.176 & 1 & .000 & & \\
\hline $\mathrm{N}$ of Valid Cases & 30 & & & & \\
\hline
\end{tabular}

a. 0 cells $(.0 \%)$ have expected count less than 5 . The minimum expected count is 6.50 .

b. Computed only for a $2 \times 2$ table

Note: $x^{2}=22.941, P=0.000<0.05$

The Intensity of Motivation Crosstabulation

\begin{tabular}{|c|c|c|c|c|c|}
\hline & Value & df & $\begin{array}{l}\text { Asymp. Sig. } \\
\text { (2-sided) }\end{array}$ & $\begin{array}{l}\text { Exact Sig. } \\
\text { (2-sided) }\end{array}$ & $\begin{array}{l}\text { Exact Sig. } \\
\text { (1-sided) }\end{array}$ \\
\hline Pearson Chi-Square & $26.250^{\mathrm{a}}$ & 1 & .000 & & \\
\hline Continuity Correction ${ }^{\mathrm{b}}$ & 22.634 & 1 & .000 & & \\
\hline Likelihood Ratio & 34.107 & 1 & .000 & & \\
\hline Fisher's Exact Test & & & & .000 & .000 \\
\hline Linear-by-Linear Association & 25.375 & 1 & .000 & & \\
\hline $\mathrm{N}$ of Valid Cases & 30 & & & & \\
\hline
\end{tabular}

a. 0 cells $(.0 \%)$ have expected count less than 5 . The minimum expected count is 7.00 .

b. Computed only for a $2 \times 2$ table

Note: $x^{2}=26.250, P=0.000<0.05$ 
In order to make the data more convincing, 15 high achievers and 15 low achievers are selected from different universities in Xia Sha Higher Educational Zone to conduct in-depth interviews. Table 2 presents the result of Chi-square tests. In the Chi-square tests, the most dramatic difference is in the aspect of motivation types and the intensity of motivation. The data is obtained: $\mathrm{x}^{2}=22.941 \quad(\mathrm{P}=0.000<0.05), \mathrm{x}^{2}=26.250(\mathrm{P}=0.000<0.05)$. Practice has proved that all 15 high achievers hold integrative motivation, some of them hold the mixed motivation. 2 of the 15 low achievers hold integrative motivation. $80 \%$ of high achievers spare no efforts to study and $20 \%$ believe they work harder than others. $53.3 \%$ of low achievers consider they don't work hard enough and $46.7 \%$ think they work as hard as everyone else. Regarding situational motivation, over 80 percent of the participants believe that the strong affinity and energy type teachers will promote their learning, but authoritative type teachers will hinder their subjective initiative.

From the findings, we conclude that teachers should establish people-oriented, sustainable development education concept to guide learners' interest, to recognize learners' motivation and at the same time raise learners' integration motivation. In learning process, teachers should raise learners' integration motivation by correcting their negative stereotypes towards English speaking countries and people. Secondly, teachers should take different measures to create a relaxed environment to eliminate students' anxiety caused by psychological barriers and thus to increase learners' self-confidence. Finally, the traditional teaching method of teacher-centered should give way to the new teaching method. Teachers should get involved in students' lives, understanding students' ideological and learning dynamic. In addition, learners should also change the misconceptions to the English-speaking countries, try to share the ideas they obtain in the process of learning, and actively participate in English learning.

\subsection{Strategies}

The frequencies of response (in percentage), mean, and standard deviations for the ten items are presented in the study. The date display that $0.75 \%$ of learners reflect positively in English communication activities and $17.63 \%$ often take an active part in, but seldom share their ideas. $18.21 \%$ of them seldom participate in English communication activities, but when participating, they will response positively. $10.41 \%$ neither participate frequently nor react actively, $13 \%$ have not participated in any communication activities. In the area of learning method, only $12.43 \%$ of learners often compare the differences between mother tongue with second language, they believe the method is meaningful, $40.75 \%$ will compare when meeting particular problems, $27.75 \%$ do comparison when asked by teachers, and the remaining $19.08 \%$ of learners think the method is meaningless. By analyzing the data, we find that learners rarely analyze the form of language in order to find out the rules of learning. And learners seldom link up new knowledge with the old one. That is to say, they don't have the appropriate strategies to approach their language learning.

As for learners' learning initiative, statistics indicate that $28.04 \%$ of participants solve unclear problems with the help of dictionary, network and books; $55.2 \%$ of the participants choose to ask teachers or classmates; $17.05 \%$ do not ask, though they do not understand. The item "whether you often practice silence repetition and imitate the language structure" receives negative loading. $27.46 \%$ of participants often practice and insist on practicing, $41.04 \%$ often practice intermittently. Whereas, $31.5 \%$ of the participants neither practice nor think it meaningful. When asked about study plan, whose who often make plans and comply with it is only $11.27 \%$, compare with $74.8 \%$ of the participants who are unable to fulfill plans even they have plans.

When concerning learners' language learning consciousness, the ability to employ strategy, the sense of teamwork, $17.05 \%$ of the participants fully understand the conditions conducive to their English learning, and can create these conditions, $29.77 \%$ of participants understand, but not initiative to create the conditions, those who have a basic understanding of the conditions and can create conditions for learning, or who have a basic understanding, but do not consider creating conditions for learning are only $19.77 \%$ and $12.77 \%$ respectively, $10.69 \%$ of the participants do not know at all. When talking about learning methods, the majority of the participants $(60.99 \%)$ 
use different learning methods; $39.02 \%$ of the participants just listen to teachers and have no initiative to use other learning methods. Only $32.15 \%$ of learners believe the teamwork study can get more feedback, Thus we infer that learners in this area are lack of cooperation and teamwork spirits.

Table 3. The Chi-Square Tests

Cross Lingual Comparisons Crosstabulation

\begin{tabular}{|l|l|l|l|}
\hline & Value & df & Asymp. Sig. (2-sided) \\
\hline Pearson Chi-Square & $22.941^{\mathrm{a}}$ & 2 & .000 \\
Likelihood Ratio & 29.274 & 2 & .000 \\
Linear-by-Linear Association & 18.710 & 1 & .000 \\
N of Valid Cases & 30 & & \\
\hline
\end{tabular}

a. 4 cells $(66.7 \%)$ have expected count less than 5 . The minimum expected count is 3.00 . Note: $x^{2}=22.941, P=0.000<0.05$

Induction Crosstabulation

\begin{tabular}{|l|l|l|l|}
\hline & Value & df & Asymp. Sig. (2-sided) \\
\hline Pearson Chi-Square & $30.000^{\mathrm{a}}$ & 2 & .000 \\
Likelihood Ratio & 41.589 & 2 & .000 \\
Linear-by-Linear Association & 23.200 & 1 & .000 \\
N of Valid Cases & 30 & & \\
\hline
\end{tabular}

a. 2 cells (33.3\%) have expected count less than 5 . The minimum expected count is 2.50 . Note: $x^{2}=30.000, P=0.000<0.05$

\begin{tabular}{|l|l|l|l|}
\hline & Value & df & Asymp. Sig. (2-sided) \\
\hline Pearson Chi-Square & $22.941^{\mathrm{a}}$ & 2 & .000 \\
Likelihood Ratio & 29.274 & 2 & .000 \\
Linear-by-Linear Association & 18.376 & 1 & .000 \\
N of Valid Cases & 30 & & \\
\hline
\end{tabular}

a. 2 cells (33.3\%) have expected count less than 5 . The minimum expected count is 1.50 . Note: $\mathrm{x}^{2}=22.941, \mathrm{P}=0.000<0.05$

Elaboration Crosstabulation

\begin{tabular}{|l|l|l|l|}
\hline & Value & df & Asymp. Sig. (2-sided) \\
\hline Pearson Chi-Square & $26.250^{\mathrm{a}}$ & 2 & .000 \\
Likelihood Ratio & 34.107 & 2 & .000 \\
Linear-by-Linear Association & 21.000 & 1 & .000 \\
N of Valid Cases & 30 & & \\
\hline
\end{tabular}

a. 4 cells $(66.7 \%)$ have expected count less than 5 . The minimum expected count is 3.50 . Note: $x^{2}=26.250, P=0.000<0.05$

\begin{tabular}{|l|l|l|l|}
\hline \multicolumn{3}{|c|}{ Cooperation Crosstabulation } \\
\hline & Value & df & Asymp. Sig. (2-sided) \\
\hline Pearson Chi-Square & $22.286^{\mathrm{a}}$ & 2 & .000 \\
Likelihood Ratio & 28.839 & 2 & .000 \\
Linear-by-Linear Association & 21.526 & 1 & .000 \\
N of Valid Cases & 30 & & \\
\hline
\end{tabular}


a. 2 cells (33.3\%) have expected count less than 5. The minimum expected count is 2.00 . Note: $\mathrm{x}^{2}=22.286, \mathrm{P}=0.000<0.05$

Detailed explanations of the 6 significant differences are summarized in Table 3, including the number and title of the significant differences and the number and statement of the items. The results of the study indicate that language learning strategy plays an important role in second language learning and it makes all the differences between high achievers and low achievers.

Contrasting 15 high achievers with 15 low achievers, all 15 excellent learners pay attention to the form and the significance of language. 7 out of the 15 low achievers claim they don't value the meaning of language, 4 learners don't value language form, 4 neither value the form nor the meaning of language . Regarding to clarification and verification strategies, 15 high achievers' first thought is solving problems by active data access. Among 15 low achievers, $40 \%$ of them ignore problems they meet, $40 \%$ of them choose to ask teachers and classmates, and only 20 percent say their first thought is solving problems by active data access sometimes. By analyzing the date of the unvoiced repetition investigation, no one among the 15 low achievers can keep up the practice for a long time. In the test of self-management, $80 \%$ of the participants have never created a strategy, about $13.33 \%$ of participants often create a strategy but not follow it. Only about $6.67 \%$ of the participants create a strategy occasionally and comply with it. When interviewed, 15 high achievers also show their advantage in teamwork.

The data also shows that participants pay attention to the form of language, but they rarely highlight the significance of language. In addition, they are lack of autonomous learning ability and don't stress on the process of language learning. It also reveals that learners' ability to employ strategy and teamwork are not optimistic. That is to say, they do not have the appropriate strategies to achieve their language learning in general. The phenomenon should arouse our attention.

Learning strategies are skills, and with the advantage they will reflect more quickly. A good learner will be a learner who has grasped the strategies described in the study. In a word, in English teaching, teachers should guide learners to participate in English learning actively, emphasize the importance of the learning process, lead them to find suitable learning strategies and use strategies flexibly. In addition, it is very important for teachers to lead learners both concentrate on the form and the significance of language, regard language as a system, guide learners to compare native language with target language in learning, help learners get rid of "Dumb English" or "Deaf English". Teachers should also increase cooperative methods in teaching to enhance learners' sense of teamwork. eventually, learners themselves should strengthen their ability of strategy employment.

\subsection{Personality}

In order to verify whether characteristics have an impact on the effects of second language acquisition, this study set 7 questions and mainly a test of the personality type, stress tolerance, a spirit of adventure, tolerance of ambiguity and learning perseverance. The content of measurement in the following table presents learners' response in seven major areas: (1) learners' selfassessment personality; (2) response of failure to important English exam; (3) performance when facing pressure; (4) expectation on living conditions; (5) situation of tolerate and understanding others; (6) different cultural attitudes; (7) time duration of English articles daily reading.

Table 4 displays that the personality types, pressure endurance, spirit of adventure and tolerance of ambiguity are not invariably linked. According to data, proportion of extroverted learners is the highest and the ability of learners' pressure tolerance is of great advantage. Moreover, most learners are full of adventure and willing to accept challenges. At the same time, they do a good job in tolerating and understanding others, willing to accept foreign culture, and have a high tolerance for ambiguity. But they fail in perseverance, only $7.23 \%$ of participants read daily and can insist on more than one year. 
Table 4. Personality Test to English Majors in Xia Sha Higher Educational Zone

\begin{tabular}{|c|c|c|c|}
\hline Item & Measurements & Mean & Std. Deviation \\
\hline $\begin{array}{l}\text { Personality } \\
\text { type }\end{array}$ & $\begin{array}{l}\text { 1. An outgoing personality with strong curiosity }(42.20 \%) \\
\text { 2. Introverted personality and poor in communication } \\
(27.17 \%) \\
\text { 3. Two-way personality disorders, a little extroverted } \\
(15.03 \%) \\
\text { 4. Two-way personality disorders, a little introverted } \\
(15.61 \%)\end{array}$ & 3.8584 & 1.1463 \\
\hline \multirow[t]{2}{*}{$\begin{array}{l}\text { Pressure } \\
\text { tolerance }\end{array}$} & $\begin{array}{l}\text { 1. Analyze every failure to find its cause }(25.72 \%) \\
\text { 2. Need long time to accept defeat }(43.64 \%) \\
\text { 3. Distressed for failure and escape tasks }(18.50 \%) \\
\text { 4. Anxiety, fear of failure }(12.43 \%)\end{array}$ & 4.0607 & 1.1169 \\
\hline & $\begin{array}{l}\text { 1. Positive and optimistic to find a solution }(28.90 \%) \\
\text { 2. Feeling depressed, but can adjust }(43.06 \%) \\
\text { 3. Feel stressed for a long time }(17.63 \%) \\
\text { 4. Confused and despair }(10.41 \%)\end{array}$ & 2.4653 & 0.807 \\
\hline $\begin{array}{l}\text { Spirit of } \\
\text { adventure }\end{array}$ & $\begin{array}{l}\text { 1. Moment full of challenge (43.06\%) } \\
\text { 2. Ease and occasionally some challenges }(28.61 \%) \\
\text { 3. Live in peace and with on challenges }(28.32 \%)\end{array}$ & 2.474 & 0.8083 \\
\hline \multirow[t]{2}{*}{$\begin{array}{l}\text { Tolerance of } \\
\text { ambiguity }\end{array}$} & $\begin{array}{l}\text { 1. Empathy, can fully understand other people's feelings } \\
(26.88 \%) \\
\text { 2. Willing to listen, but can't fully understand other } \\
\text { people's feelings ( } 30.35 \%) \\
\text { 3. Cannot understand the feelings of others }(42.78 \%)\end{array}$ & 2.5867 & 0.8151 \\
\hline & $\begin{array}{l}\text { 1. Curious and willing to accept }(30.06 \%) \\
\text { 2. Willing to know but can not accept }(48.84 \%) \\
\text { 3. Cannot stand the cultural differences }(21.10 \%)\end{array}$ & 2.6908 & 0.7992 \\
\hline $\begin{array}{l}\text { Learning } \\
\text { perseverance }\end{array}$ & $\begin{array}{l}\text { 1. More than one year }(7.23 \%) \\
\text { 2. A few months }(19.65 \%) \\
\text { 3. A few weeks }(24.28 \%) \\
\text { 4. Several days }(14.16 \%) \\
\text { 5. A day to hang on }(34.68 \%)\end{array}$ & 3.4942 & 1.3324 \\
\hline
\end{tabular}

The results are consistent with the findings of the correlations between personality and English achievements which show that learners' personality is significantly related to achievements. Table 4 presents the detailed mean score of each item. The most dramatic differences are "personality type" (mean=3.8584, $\mathrm{SD}=1.1463)$; "pressure tolerance" (mean=4.0407, $\mathrm{SD}=1.1169)$; "learning perseverance" (mean=3.4942, $\mathrm{SD}=1.3324)$.

Table 5. The Chi-Square Tests

Pressure tolerance Cross tabulation

\begin{tabular}{|l|l|l|l|}
\hline & Value & df & Asymp. Sig. (2-sided) \\
\hline Pearson Chi-Square & $24.000^{\mathrm{a}}$ & 3 & .000 \\
Likelihood Ratio & 33.271 & 3 & .000 \\
Linear-by-Linear Association & 21.324 & 1 & .000 \\
N of Valid Cases & 30 & & \\
\hline
\end{tabular}

a. 6 cells $(75.0 \%)$ have expected count less than 5. The minimum expected count is 3.00 . Note: $x^{2}=24.000, P=0.000<0.05$ 
Learning perseverance Crosstabulation

\begin{tabular}{|l|l|l|l|}
\hline & Value & df & Asymp. Sig. (2-sided) \\
\hline Pearson Chi-Square & $30.000 \mathrm{a}$ & 2 & .000 \\
Likelihood Ratio & 41.589 & 2 & .000 \\
Linear-by-Linear Association & 23.200 & 1 & .000 \\
N of Valid Cases & 30 & & \\
\hline
\end{tabular}

a. 2 cells $(33.3 \%)$ have expected count less than 5 . The minimum expected count is 2.50 . Note: $x 2=30.000, P=0.000<0.05$

Table 5 shows that the wide gaps exist between high achievers and low achievers in pressure tolerance and learning perseverance. Comparing 30 interviewees, 5 extroverted participants of the 15 high achievers analyze every failure to find its cause to avoid failure again when failed in an important test, 8 two-way personality participants analyze failure to find its cause, others spend a long time to accept defeat. Facing exam failure, 15 low achievers fear of examinations or feel anxious, none of them are optimistic about the failure. Facing pressure, 15 high achievers show better capacity to adjust than 15 low achievers. What's more, pressure plays an improving role to the high achievers. In the interview, the most obvious difference is in perseverance.9out of the 15 high achievers can insist on daily reading for more than a year, 6 of them last for months. However, 7 out of the 15 low achievers persist in a few weeks, 3 participants persist in a few days, the remaining 5 a day to hang on. Therefore, perseverance can affect the effects in second language acquisition and the influence is more prominent. The statistics also show that personality do not influence the effects of second language acquisition, because $66.66 \%$ of high achievers are extroverted or partial extroverted while $80 \%$ of low achievers are extroverted. The study also shows the spirit of adventure and the second language acquisition effects are not invariably linked.

In sum, according to the different characters of students, teachers should take corresponding measures. Firstly, teachers should understand the differences among students' characters to take appropriate teaching methods. Secondly, teachers need to guide learners deal with pressure actively. Thirdly, teachers should attach more importance to the prevention of psychological problems, focus on the introverted learners, for they often have the feeling of inferiority, and psychological anxiety is usually the reason of poor study result. Teachers should help these learners build up confidence and help them fit in through psychological counseling. And teachers should also shape learners' learning perseverance by means of long-term task training and target incentives. Learners should also cultivate their own characters to foster strengths and circumvent weaknesses, adjust their attitude actively when facing pressure, learn to embrace ambiguity, focus on perseverance training and try to struggle for sustained goals.

\section{Conclusion}

This study is significant for both learners and teachers. It helps learners to exploits their own language learning potential and promotes the practice of second language acquisition. The key to improve the efficiency of second language acquisition is to create a personalized learning environment to stimulate learners' interest, which needs learners find a suitable way of their own to learn and transfer "teaching" into "mobilizing" learners' initiation, and this will help learners break though the limits of short-term utilitarian goals, a genuine sustainable state of second language acquisition will be reached. In the process of teaching, this research will be helpful for teachers to master the learners' individual differences and guide teachers to achieve the optimal teaching effect with proper methods. Ultimately, the study has proposed innovative ideas to conduct further research in second language acquisition. 


\section{References}

1. Cored, S P. The Significance of Learner's Errors [J]. International Review of Applied Linguistics, 1967, (5): 161-170.

2. Dai, Yun Cai, Cui, wen Qi. Ten Principles of Foreign Language Teaching Based on Second Language Acquisition[J].Journal of PLA University of Foreign Languages, 2014, 37(6): 31-39.

3. Dornyei, Z. Teaching and Researching Motivation [M]. Beijing: Foreign Language Teaching and Research Press, 2005: 1-15.

4. Ellis, R. Classroom Learning Styles and Effect on Second Language Acquisition: A study of two learners [J] System, 1989, (7): 249-262.

5. Gardner, R C. Social Psychology and Second Language Learning [M]. London: Edward Arnold. 1985.

6. Huang, Weiying. A Review on Learning Environment, Individual Differences and Pragmatic Competence[J]. Modern foreign languages, 2014, 37(4): 579-582.

7. O'Malley, J A., Chamot \& Walker, C. Some applications of cognitive theory to second language acquisition [J]. Studies in Second Language Acquisition, 1987, (9): 287-306.

8. Skehan, P. Individual Difference in Second Language Acquisition [M]. London: Edward Amold, 1989: 65-214.

9. Wang Lulu, Dai, Weidong. A Survey of Research Methods in Second Language Acquisition[J]. Foreign language world, 2014, 164(5): 29-37. 